\title{
METAFORA DALAM NOVEL SINGGASANA TAK BERTUAH \\ KARYA MIRA PASOLONG DAN \\ IMPLIKASINYA DALAM PEMBELAJARAN
}

\author{
Baharuddin Nurdin, Muslimin, Herman Didipu \\ Magister Pendidikan Bahasa Indonesia, Pascasarjana Universitas Negeri Gorontalo
}

\begin{abstract}
ABSTRAK
Tujuan penelitian ini yaitu (1) Mendeskripsikan jenis-jenis metafora yang terdapat dalam novel "Singgasana Tak Bertuah" karya Mira Pasolong. (2) Mendeskripsikan fungsi metafora yang terdapat dalam novel "Singgasana Tak Bertuah" karya Mira Pasolong. (3) Mendeskripsikan implikasi metafora dalam novel "Singgasana Tak Bertuah" karya Mira Pasolong pada pembelajaran di sekolah. Metode yang digunakan dalam penelitian ini yaitu metode kualitatif. Prosedur penelitian dilakukan secara bertahap, mulai dari tahap persiapan, tahap analisis data, dan tahap akhir. Teknik pengumpulan data yang digunakan dalam penelitian ini adalah membaca, mencatat kata atau kalimat dan mengklasifikasikan data ke dalam tabel. Teknik analisis data yang digunakan adalah teknik perluas. Adapun langkah - langkah dalam menganalisis data yaitu : 1) mengidentifikasi dan menginventarisasi kata atau kalimat yang mengandung metafora dalam novel Singgasana Tak Bertuah karya Mira Pasolong, 2) mengklasifikasikan data hasil yang telah dicatat berdasarkan gaya bahasa metafora, 3) menafsirkan fungsi gaya bahasa metafora yang ada di dalam novel Singgasana Tak Bertuah karya Mira Pasolong, dan 4) mendeskripsikan atau menjelaskan metafora yang terdapat dalam novel Singgasana Tak Bertuah karya Mira Pasolong ke dalam suatu bentuk laporan penelitian. Berdasarkan penelitian yang telah dilakukan, peneliti menemukan 4 jenis kalimat yang mengandung metafora dalam novel Singgasana Tak Bertuah, yaitu metafora antropomorfik, metafora binatang, metafora sinestesis, dan metafora abstrak ke konkret. Berdasarkan fungsi metafora, peneliti menemukan ada 4 fungsi yaitu, fungsi emotif, fungsi konatif, fungsi puitis, dan fungsi referensial. penelitian ini memiliki implikasi (keterkaitan) dengan kegiatan pembelajaran di sekolah khususnya di tingkat SMA semester 1. Sebagai media pembelajaran, novel dapat diimplikasikan dalam kegiatan belajar pada KD 3.1 memahami struktur dan kaidah teks cerita sejarah, berita, iklan, editorial/opini, dan cerita fiksi dalam novel baik melalui lisan maupun tulisan. KD. 4.1 menginterpretasikan makna teks cerita sejarah, berita, iklan, editorial/opini, dan cerita fiksi dalam novel baik secara lisan maupun tulisan.
\end{abstract}

Kata kunci: Metafora, Novel, Implikasi Pembelajaran

\section{PENDAHULUAN}

Manusia merupakan makhluk hidup yang memiliki jiwa sosial yang tinggi. Oleh karena itu, manusia sering juga disebut manusia yang berbudaya. Hal ini sesuai dengan yang dikemukakan oleh Markhamah, dkk (2009:1), bahwa manusia adalah makhluk yang berbudaya. Sebagai makhluk berbudaya, manusia dianugerahi bahasa. Dengan bahasa kita dapat saling berinteraksi dengan sesama manusia. Sebagai alat komunikasi, bahasa digunakan hampir di setiap kegiatan, tidak terbatas pada satu kegiatan tertentu.
Djajasudarma (2012:53) mengatakan bahwa bahasa digunakan dalam kesempatan yang lebih luas, hampir pada semua kegiatan sampai pada mimpi pun kita menggunakan bahasa.

Bahasa terdiri atas dua jenis, yaitu bahasa lisan dan bahasa tulis. Bahasa lisan merupakan bahasa yang disampaikan pembicara kepada pendengar secara langsung. Bahasa tulis adalah bahasa yang dituangkan ke dalam bentuk tulisan. Penggunaan bahasa tulis, tidak hanya terbatas pada buku yang bersifat ilmiah, namun juga meliputi sastra. Menurut Jazeri (2012:10), sastra merupakan karya fiksi yang 
menggunakan bahasa sebagai media penyampai pesannya. Ketika memahami sebuah karya sastra, terkadang kita salah menafsirkan makna. Hal itu dikarenakan penggunaan gaya bahasa. gaya bahasa merupakan cara penulis atau penutur mengungkapkan perasaan, ide, atau gagasan dengan tidak menggunakan kata-kata yang sesuai dengan kenyataan. Hal ini sesuai dengan yang dikemukakan oleh Tarigan (dalam Setiyaningsih, 2019:5) bahwa gaya bahasa adalah bahasa indah yang digunakan untuk meningkatkan efek dengan cara memperkenalkan serta membandingkan suatu benda atau unsur tertentu dengan benda atau unsur lain yang lebih umum. Menurut Tarigan (dalam Setiyaningsih,2019:7), gaya bahasa terbagi atas empat, yaitu gaya bahasa perbandingan, gaya bahasa pertentangan, gaya bahasa pertautan, dan gaya bahasa perulangan. Dalam penelitian ini, peneliti memfokuskan pada gaya bahasa perbandingan jenis metafora.

Metafora sering digunakan dalam berbagai interaksi, baik lisan maupun tulisan. Dalam hal ini, yang dimaksud oleh peneliti adalah metafora yang digunakan dalam karya sastra tulis berbentuk novel. Novel adalah salah satu jenis karya sastra yang menceritakan suatu peristiwa atau kejadian. Hal yang serupa juga dikemukakan oleh Abrams (dalam Raharjo,2018:19) bahwa novel merupakan salah satu narasi sastra yang isinya menceritakan berbagai peristiwa. Metafora terbagi atas empat kategori: (1) Metafora antropomorfis (anthropormic metaphor), (2) Metafora kehewanan (animal metaphor), (3) Metafora dari konkret ke abstrak (from concert to abstract), (4) Metafora sinestesis (synesthetic metaphor). Menurut Jacobson (dalam Soeparmo,2013:18-19) Enam fungsi bahasa metafora meliputi, (1) Fungsi emotif yaitu bagaimana seseorang mengungkapkan perasaan gembira, kesal, sedih, bahagia dan sebagainya. (2) fungsi konatif, mengacu pada efek pesan pada penerima, (3) fungsi referensial digunakan untuk membicarakan suatu permasalahan dengan topik tertentu, menempatkan prioritas utama dalam komunikasi yang objektif dan faktual. (4) fungsi puitis untuk menyampaikan suatu amanat atau pesan tertentu. (5) fungsi patik digunakan untuk sekedar kontak dengan orang lain. (6) fungsi metalingual apabila yang dibicarakan masalah bahasa adalah menggunakan bahasa tertentu/ mengidentifikasi kode yang digunakan.

\section{METODE PENELITIAN}

Penelitian ini merupakan jenis penelitian dokumentasi. Dokumen yang dimaksud berupa novel. Penelitian metafora dalam novel Singgasana Tak Bertuah karya Mira Pasolong ini merupakan penelitian kualitatif. Penelitian ini digunakan dengan maksud untuk mendeskripsikan data-data yang ditemukan pada sumber data. Hal ini sesuai dengan yang dikemukakan oleh Djajasudarma (1993:8), bahwa metode penelitian deskriptif adalah metode yang bertujuan membuat deskripsi, maksudnya membuat gambaran, lukisan secara sistematis, faktual dan akurat mengenai data, sifat-sifat serta hubungan fenomena-fenomena yang diteliti. Jenis penelitian yang digunakan yaitu studi naratif. Jenis penelitian ini dipilih karena peneliti berusaha menceritakan atau mendeskripsikan temuan dalam kegiatan penelitian secara apa adanya.

Data yang digunakan dalam penelitian ini adalah data primer dan data sekunder. Data primer adalah data utama yang dikumpulkan oleh peneliti. Data primer dalam penelitian ini yaitu jenis dan fungsi metafora dalam novel Singgasana Tak Bertuah karya Mira Pasolong. Adapun data sekunder yang dimaksud oleh peneliti adalah buku-buku yang berkaitan dengan penelitian yang sedang dilakukan. Menurut Arikunto (2014:172), Sumber data adalah subjek dari mana data dapat diperoleh. Adapun sumber data dalam penelitian ini adalah novel Singgasana Tak Bertuah Karya Mira Pasolong. Langkah-langkah dalam pengumpulan data yaitu : (1) menemukan data yang dimaksud berupa kata, frasa, dan kalimat yang mungkin mengandung metafora dan menggarisbawahi kalimat tersebut, mencatat kata, frasa, maupun kalimat yang sudah digarisbawahi sebelumnya, 
mengklasifikasikan kata atau kalimat yang mengandung metafora ke dalam bentuk tabel klasifikasi data. Teknik analisis yang digunakan dalam penelitian ini adalah teknik analisis bahasa yang diungkapkan oleh Zaim (2014:110), yaitu teknik perluas. Teknik perluas berguna untuk mengetahui kadar kesinoniman bila dua satuan berlainan tapi diduga bersinonim satu sama lain. Langkahlangkah dalam menganalisis data sebagai berikut.

1. Mengidentifikasi dan menginventarisasi kata atau kalimat yang mengandung metafora dalam novel Singgasana Tak Bertuah karya Mira Pasolong.

2. Mengklasifikasikan data hasil yang telah dicatat berdasarkan gaya bahasa metafora.

3. Menafsirkan fungsi gaya bahasa metafora yang ada di dalam novel Singgasana Tak Bertuah karya Mira Pasolong.

4. Mendeskripsikan atau menjelaskan metafora yang terdapat dalam novel Singgasana Tak Bertuah karya Mira Pasolong ke dalam suatu bentuk laporan penelitian.

\section{PEMBAHASAN}

Menurut jenisnya, metafora yang peneliti temukan dalam novel Singgasana Tak Bertuah ada 4 jenis, yaitu antropomorfis, metafora binatang, dan sinestesis. Contoh data yang peneliti temukan dalam novel Singgasana Tak Bertuah karya Mira Pasolong.

\section{Aku hanya berharap kesabaranku} tidak akan terkikis oleh derasnya arus penderitaan yang aku rasakan di rumah ini. (halaman 10)

Berdasarkan kalimat pada data tersebut, dapat disimpulkan bahwa frasa derasnya arus penderitaan dapat dikategorikan sebagai metafora antropomorfis. Frasa derasnya arus memiliki arti aliran air yang mengalir dengan kuat, sedangkan penderitaan adalah sesuatu yang menyusahkan yang ditanggung dalam hati. Pada frasa ini pengarang menyandingkan kata derasnya arus yang merupakan benda mati seakanakan bisa merasakan penderitaan yang hanya bisa dirasakan oleh makhluk yang bernyawa.

2. Dengan ekor mata sesekali aku meliriknya ke belakang. (hal. 282)

Data (2) merupakan metafora binatang. Hal ini ditunjukkan dengan gabungan dua buah kata yaitu ekor dan mata. Kata ekor identik dengan binatang. Ekor adalah buntut atau bagian ujung belakang badan hewan baik berupa sambungan dari tulang belakang maupun sebagai lekatan, sedangkan mata adalah bagian tubuh yang berada di kepala dan berfungsi sebagai alat penglihatan. Dengan mata kita dapat membedakan wujud, warna, dan bentuk suatu benda. Pada frasa ini pengarang menggunakan kata ekor mata yang berarti memperhatikan secara diamdiam

\section{Kutajamkan pendengaranku. Rintihan itu nampaknya berasal dari kamar Opo. (hal. 300)}

Data (3) termasuk metafora sinestesis, karena di dalam metafora ini ada perpaduan dua kata yaitu tajam dan dengar. Kata tajam adalah bermata tipis atau mudah melukai. Sedangkan kata mendengar adalah menangkap suara dengan telinga. Pada frasa ini terdapat dua indra, yaitu indra penglihatan dialihkan ke indra pendengaran.

\section{Ibunya memperkenalkan calon yang} dimaksud, yang masih bertalian darah dengannya. (hal. 59)

Data (4) termasuk jenis metafora abstrak ke konkret. Hal ini terlihat pada kata merujuknya. Bentuk dasar dari kata bertalian adalah tali. Tali merupakan alat yang bisa dilihat atau bersifat konkret, tali digunakan untuk mengikat barang/sesuatu. Darah merupakan sel plasma yang ada di dalam tubuh manusia. Darah adalah sesuatu yang abstrak. Namun dalam kalimat tersebut bertalian darah memiliki makna memiliki hubungan keluarga. 
Berdasarkan fungsinya, peneliti menemukan empat fungsi metafora dalam novel Singgasana Tak Bertuah Karya Mira Pasolong yaitu fungsi emotif, fungsi konatif, fungsi puitis, dan fungsi referensial. berikut beberapa contoh kalimat metafora dalam novel Singgasana Tak Bertuah.

1. Hujan rintik-rintik yang mengiringi kepergian kami semakin menambah gerimis di hatiku. (halaman 279)

Pada data (1) tokoh wanita mengungkapkan kesedihan hatinya karena ditinggal sang ibu untuk selama-lamanya. Padahal ia sudah berjanji akan selalu menemani sang ibu. Namun, janji tinggallah janji, sang ibu telah dipanggil menghadap sang khalik. Tokoh wanita merasa sangat sedih. Hal tersebut digambarkan melalui ungkapan "menambah gerimis di hatiku".

2. Rintihan itu nampaknya berasal dari kamar Opu. (halaman 300)

Data (2) merupakan metafora yang memiliki fungsi konatif. Fungsi ini mengacu pada efek pesan untuk penerima, serta mempengaruhi seseorang untuk melakukan sesuatu. Karena mendengar rintihan di kamar Opu, tokoh dalam novel bergegas untuk memeriksanya. Tokoh ingin mengetahui apa yang terjadi di dalam kamar Opu. Dengan respons yang sangat cepat karena takut terjadi sesuatu yang tidak diinginkan.

3. Setelah beberapa lama terdiam, Opu kemudian membuka pembicaraan intinya dia ingin membagikan hartanya yang masih tersisa kepada anak-anaknya. (halaman 291)

Data (3) termasuk data jenis metafora dengan fungsi referensial. hal ini disebabkan terdapat topik pembicaraan yang sedang terjadi dalam interaksi antar tokoh novel. Adapun topik tersebut yaitu tentang pembagian harta warisan. Hal ini dilakukan karena Opu sudah sering sakitsakitan. Ia tidak mau meninggal dalam keadaan meninggalkan masalah untuk anak-anaknya di kemudian hari.
4. Aku tidak mau terus-menerus tergantung pada orang tua. (halaman18)

Data (4) termasuk fungsi puitis karena menyampaikan pesan untuk tidak terus-menerus mengharapkan bantuan orang tua. Pesan agar kita dapat mandiri, sehingga tidak perlu lagi menyusahkan orang lain. Apalagi jika orang tua kita sudah tua, maka sudah waktunya jika kitalah yang menjadi tempat bersandar mereka di hari tua. Bukan menjadi beban yang menyusahkan mereka. Sudah cukup mereka merawat kita mulai dari kandungan hingga dewasa.

\section{IMPLIKASI PEMBELAJARAN}

Implikasi adalah keterkaitan antara objek yang diteliti dengan kegiatan pembelajaran di sekolah. Pada penelitian ini, peneliti mengimplikasikan penelitian metafora dalam novel Singgasana Tak Bertuah pada kurikulum 2013. Novel dapat dijadikan media pembelajaran Bahasa Indonesia di sekolah, khususnya di tingkat SMA kelas XII semester I. Sebagai media pembelajaran, novel dapat diimplikasikan dalam kegiatan belajar pada KD 3.1 memahami struktur dan kaidah teks cerita sejarah, berita, iklan, editorial/opini, dan cerita fiksi dalam novel baik melalui lisan maupun tulisan. KD. 4.1 menginterpretasikan makna teks cerita sejarah, berita, iklan, editorial/opini, dan cerita fiksi dalam novel baik secara lisan maupun tulisan.

\section{SIMPULAN}

Berdasarkan pembahasan di atas, maka peneliti menyimpulkan bahwa (1) dalam novel Singgasana Tak Bertuah terdapat empat jenis metafora, yaitu metafora antropomorfis, metafora binatang, metafora abstrak ke konkret, dan metafora sinestesis. (2) Fungsi metafora yang terdapat dalam penelitian ini ada empat yaitu fungsi emotif, konatif, referensial dan puitis. (3) penelitian tentang metafora dalam novel dapat diimplikasikan ke dalam pembelajaran di sekolah, baik kajian metafora maupun novel. 


\section{DAFTAR PUSTAKA}

Arikunto, Suharsimi. 2014. Prosedur Penelitian. Jakarta: PT. Rineka Cipta

Djajasudarma, T. Fatimah. 1993. Metode Linguistik. Bandung: PT. Eresco

---------, 2012. Wacana dan Pragmatik. Bandung: PT. Refika Aditama

Jazuri. 2012. Semantik, Teori Memahami Makna Bahasa. Tulungagung: STAIN Tulunggagung Press

Markhamah, dkk. 2009. Analisis Kesalahan dan Kesantunan Berbahasa. Surakarta: Muhammadiyah University Press.

Pasolong, Mira. 2011. Singgasana Tak Bertuah. Yogyakarta: Arsir Offset.

Raharjo, Hafid Purwono. 2018. Analisis Karya Sastra (Panduan Praktik Analisis Novel dan Puisi Bagi Pengajar. Sukoharjo. CV Sindunata.

Setyaningsih, Ika. 2019. Ragam Gaya Bahasa. Daerah Istimewa Yogyakarta: PT. Penerbit Intan Pariwara

Soeparno. 2013. Dasar-Dasar Linguistik Umum. Yogyakarta: Tiara Wacana.

Zaim, M. 2014. Metode Penelitian Bahasa: Pendekatan Struktural. Padang: FBS UNP Press. 